\title{
Anesthetic Drugs Accelerate the Progression of Postoperative Metastases of Mouse Tumors
}

\author{
J. ShAPIRo and J. JERSKY, Department of Surgery B, Shaare-Zedek Hospital, \\ Jerusalem, Israel \\ S. Katzav, M. Feldman, and S. Segal, Department of Cell Biology, The \\ Weizmann Institute of Science, Rehovot 76100, Israel
}

\begin{abstract}
A B S T R A C T Experiments were made to investigate the effect of four anesthetic drugs that are commonly used in surgical practice on the postoperative growth of mouse tumors in syngeneic recipients. These experiments revealed that some of the anesthetics when applied for surgical excision of the local tumor, strongly accelerated postoperative progression of spontaneous lung metastases produced by the 3LL Lewis lung carcinoma and by the B16 melanoma. Some of the drugs caused the appearance of metastases in organs, such as the liver, in which spontaneous metastases are not usually produced by these tumors. A T10 sarcoma clone that does not produce detectable metastases in immune intact mice even following intravenous injection, did produce metastases when injected into animals treated with pentothal sodium.
\end{abstract}

\section{INTRODUCTION}

Patients having undergone surgery under general anesthesia are known to be susceptible to postoperative infections and sepsis (1-4). Although the surgical procedure per se is likely to increase the probability of exposure to pathogenic microorganisms, the anesthetic drugs might contribute to the infective process by affecting the immune system. In fact, anesthetic agents were demonstrated to temporarily affect the reticuloendothelial system (5-7), decrease chemotaxis of leukocytes (8), reduce phagocytosis (9) and metabolic activity of lymphocytes $(3,10)$, impair the response of lymphocytes to mitogens $(11,12)$, and cause a temporary reduction in immunoglobulin production (13).

In view of the increasing interest in the involvement of the immune system in the control of neoplasia, the possible effect of general anesthesia on the postoperative progression of metastasis is of obvious importance. Although Pollard et al. (14) observed acceler-

Received for publication 2 October 1980 and in revised form 22 April 1981. ation of pulmonary metastasis in nonoperated tumorbearing rats following treatment with halothane, chloroform, and ether, we found no recorded studies on the effects of anesthetics following radical surgery of tumors. To approach this question, we studied the effects of anesthetic drugs generally used in surgical practice on the postoperative development of metastasis in two systems of metastatic mouse tumors: the 3LL Lewis lung carcinoma and the B16 melanoma, both originated in C57BL/6 $\left(\mathrm{H}-2^{\mathrm{b}}\right)$ mice $(15,16)$. After subcutaneous or intrafootpad inoculation, and while growing locally, these tumors produce spontaneous lung metastases. We tested the effect of the anesthetic drugs pentothal sodium, halothane, nitrous oxide $\left(\mathrm{N}_{2} \mathrm{O}\right)$, and kethalar on the development of lung metastasis following radical excision of the local tumor. Pentothal sodium and $\mathrm{N}_{2} \mathrm{O}$ were also tested for their effects on the production of metastasis by cloned cell populations of the T10 sarcoma $(17,18)$, a methylcholanthrene-induced tumor in a $(\mathrm{C} 3 \mathrm{Heb} \times \mathrm{C} 57 \mathrm{BL} / 6) \mathrm{F}_{1}$ mouse (19).

Our studies indicated that some of the anesthetic drugs significantly enhanced the development of postoperative metastasis.

\section{METHODS}

Mice. Inbred 2-3-mo-old male C57BL/6 and (C3Heb $\times$ C57BL/6)F $F_{1}$ mice were supplied by the Animal Breeding Center of the Weizmann Institute of Science.

Tumors. We used the Lewis lung carcinoma (3LL) and the B16 melanoma, both of which developed spontaneously in C57BL/6 mice $(15,16)$ and were maintained by subcutaneous transfers in syngeneic male mice. In addition, we used two lines (IC9 and IE7) derived by cloning $(17,18)$ in semisolid agar of a sarcoma (T10) induced by methylcholanthrene in $(\mathrm{C} 3 \mathrm{Heb} \times \mathrm{C} 57 \mathrm{BL} / 6) \mathrm{F}_{1}$ mice (18) and kept by subcutaneous transplantation in syngeneic $F_{1}$ mice. Single cell suspensions of solid tumors were prepared by treatment of minced tumor tissue with a solution of $0.3 \%$ trypsin (hog pancrease, Grand Island Biological Co. Grand Island, N. Y.). The trypsin-treated cells were washed three times with phosphate- 
buffered saline (PBS), ${ }^{1} \mathrm{pH} 7.4$, and resuspended in PBS for inoculation.

Anesthetic drugs. The doses of pentothal sodium and kethalar used in the experiments were calculated according to mouse body weight, as done in surgery of humans. Halothane and $\mathrm{N}_{2} \mathrm{O}$ were used in sufficient doses to cause anesthesia until the operation was over.

Pentothal sodium was diluted in PBS and $30 \mathrm{mg} / \mathrm{g}$ of mouse weight was injected intravenously. Halothane (fluothane) was administered by placing each mouse in a closed jar in the presence of a sponge soaked in the anesthetic and letting the mouse inhale the drug for about $3 \mathrm{~min}$; amputation was performed immediately. $\mathrm{N}_{2} \mathrm{O}$ was administered by placing each mouse in a glass tube open at one end to room air and blowing the gas into the tube at a rate of $50 \mathrm{ml} / \mathrm{min}$. The gas thus mixed with room air and the mouse was generally anesthetized for $\sim 3 \mathrm{~min}$. Kethalar $(50 \mathrm{mg}$ ) was diluted in PBS and $0.24 \mathrm{mg}$ of the diluted drug was injected intravenously into each mouse.

In vivo assay for metastasis formation. C57BL/6 male mice were injected into the right hind footpad with $10^{5}$ viable $3 \mathrm{LL}$ cells or with $10^{6} \mathrm{~B} 16$ melanoma cells. When the tumor reached $\sim 6-8 \mathrm{~mm}$ Diam (as measured with calipers), the mice were exposed to different anesthetic drugs and after a general anesthesia $\sim 3-5 \mathrm{~min}$, the tumor-bearing legs were amputated Surgery was performed using a $3 / 0$ (2) silk tie, which was ligated beyond the iliofemoral joint of the hind leg to prevent bleeding. Heavy scissors were used to amputate the leg above the knee.

To determine metastatic development, mice were inoculated $10 \mathrm{~d}$ after surgery with $25 \mu \mathrm{g} /$ mouse of 5-fluoro-2'-deoxyuridine (FUdR) and $30 \mathrm{~min}$ later with $1 \mu \mathrm{Ci}$ of 5-[125I]iodo2 '-deoxyuridine (20). IUdR is a thymidine analogue incorporated specifically into DNA by labeling cells in S phase. In order to inhibit the endogenous formation of thymidine precursors that compete with IUdR for incorporation into DNA (21), each animal was given nonradioactive FUdR before injection of ${ }^{125} \mathrm{I}-\mathrm{UdR}$. In the experiment done with $3 \mathrm{LL}$ 24-h after ${ }^{125}$ I-UdR injection, mice were killed and the weight of lungs determined. In parallel, the degree of ${ }^{125}$ I-UdR incorporation by the various organs was measured using a Packard gamma spectrometer. In experiments done with the B16 melanoma, the rate of ${ }^{125} \mathrm{I}-\mathrm{UdR}$ incorporation into the various organs was determined $48 \mathrm{~h}$ after ${ }^{125} \mathrm{I}$-UdR injection.

The in vivo assay for experimental pulmonary metastasis formation by the T10 clones (IE7 and IC9) was performed by injecting $1 \times 10^{6}$ viable tumor cells intravenously to $(\mathrm{C} 3 \mathrm{H} / \mathrm{eb}$ $\times$ C57BL/6)F $F_{1}$ mice and weighing their lungs $15 \mathrm{~d}$ after injection.

The effect of anesthetic drugs on the development of pulmonary metastases by those clones was tested by exposing syngeneic $F_{1}$ mice to the anesthetic drugs before intravenous inoculation of tumor cells. $15 \mathrm{~d}$ later, the lungs were photographed (Figs. 2 and 3) after treatment according to Wexler's technique (22) that enables better visualization and counting metastases.

To provide evidence for the validity of the parameters used to measure metastatic growth, different doses of T10 tumor cells (clone IE7) were injected intravenously to (C3Heb $\times \mathrm{C} 57 \mathrm{BL} / 6) \mathrm{F}_{1}$ male mice; the doses were $5 \times 10^{4}, 1 \times 10^{5}$, $5 \times 10^{5}$ and $1 \times 10^{6}$ (Table I). $14 \mathrm{~d}$ later the number of pulmonary metastatic nodules was determined and both the weight of lungs and ${ }^{125} \mathrm{I}-\mathrm{UdR}$ incorporation into the lungs were assessed according to the method described by Bonmassar et

${ }^{1}$ Abbreviations used in this paper: FUdR, 5-fluoro-2deoxyuridine; IUdR, iododeoxyuridine; PBS, phosphate-buffered saline. al. (20). Metastatic tumor nodules in the lungs were enumerated according to Wexler's technique (22). Briefly, mice were killed and injected through the trachea with $2 \mathrm{ml}$ of $15 \%$ India ink. Due to uptake of ink particles the lungs became stained deep black. The stained lungs were excised and placed for at least $5 \mathrm{~min}$ in a glass beaker, under running tap water, to remove excess ink, and fixed in a solution composed of $100 \mathrm{ml}$ of $70 \%$ alcohol, $10 \mathrm{ml}$ of formaldehyde, and $5 \mathrm{ml}$ of glacial acetic acid. When left in this solution for $24 \mathrm{~h}$, the lung metastases became permanently bleached. Separate groups of mice that had been injected intravenously with a given number of tumor cells were killed on the same day. Their lungs were excised and both their weight and the degree of ${ }^{125}$ I-UdR incorporation were determined.

Histology. Multiple histological sections were performed on mice in those experiments where the $3 L L$ tumor was used. The sections included lungs, liver, spleen, kidneys, and bone marrow originating in femoral and tibial bones of the hind legs. The examined organs were fixed in Bouin's solution for $24 \mathrm{~h}$ washed and replaced in a solution of $70 \%$ ethanol; the sections were then stained with hematoxylin and eosin.

Statistical analysis. The spread of metastasis is most probably governed by a nonrandom multifactorial mode of distribution. Hence, the incidence of metastases and their homing to a particular organ cannot be analyzed using conventional statistical tests that apply to normal distribution events. Therefore, the Mann-Whitney $U$ test was chosen for the statistical analysis of the data in the present work (23).

\section{RESULTS}

We first tested whether a correlation exists among the various parameters used in the present study to assess tumor load in lung tissues (i.e., number of pulmonary metastatic nodules, weight of lungs, and ${ }^{125} \mathrm{I}-\mathrm{UdR}$ incorporation by lung tissues). Different groups of mice were inoculated intravenously with graded numbers of tumor cells (Table I). At the indicated time intervals, mice were killed, their lungs were excised, and the metastatic load was assessed using the above-mentioned parameters. Table I indicates that a good correlation exists between the three different parameters. This enabled us to use alternatively one or two of these parameters in each experiment.

We then studied the effects of the various anesthetic drugs applied for surgical removal of the local 3LL tumor on the development of postsurgical metastases. C57BL/6 mice were inoculated intrafootpad with 1 $\times 10^{5}$ 3LL tumor cells. When the tumor reached 6-8 $\mathrm{mm}$ Diam, the mice were exposed to the anesthetic drugs (pentothal sodium, halothane, kethalar, or $\mathrm{N}_{2} \mathrm{O}$ ) and the legs with the local tumors were amputated. Control tumor-bearing mice were amputated without anesthesia. To assay the extent of metastatic growth we weighed the lungs and measured the incorporation of ${ }^{125} \mathrm{I}-\mathrm{UdR}$ in the lungs, liver, and spleen $10 \mathrm{~d}$ after surgery; in addition the histology of the organs was examined.

The results (Table II) indicated that all four anesthetic drugs increased the development of lung metas- 
TABLE I

Number of Pulmonary Metastatic Nodules, Weight of Lungs, and ${ }^{125 I-U d R}$ Incorporation in the Lungs of Mice Injected Intravenously with Graded

Numbers of T10 Cloned (IE7) Tumor Cells

\begin{tabular}{ccccccc}
\hline Group & $\begin{array}{c}\text { No. of } \\
\text { mice per } \\
\text { group }\end{array}$ & $\begin{array}{c}\text { No. of T10 clone } \\
\text { tumor cells (IE7) } \\
\text { injected intravenously }\end{array}$ & $\begin{array}{c}\text { No. of } \\
\text { pulmonary } \\
\text { metastatic } \\
\text { nodules* }\end{array}$ & Weight of lungs & i2sI-UdR incorporation \\
\hline & & & & $m^{*}$ & \multicolumn{2}{c}{$c m^{*}$} \\
1 & 5 & - & - & $197 \pm 7$ & $845 \pm 256$ \\
2 & 7 & $5 \times 10^{4}$ & $9 \pm 4$ & $222 \pm 28(0.05)$ & $3,986 \pm 1,443 \quad(0.008)$ \\
3 & 6 & $1 \times 10^{5}$ & $22 \pm 5$ & $254 \pm 26(0.019)$ & $7,510 \pm 1,505(0.001)$ \\
4 & 7 & $5 \times 10^{5}$ & $32 \pm 9$ & $421 \pm 30(0.009)$ & $29,921 \pm 18,981(0.005)$ \\
5 & 11 & $1 \times 10^{6}$ & $112 \pm 8$ & $845 \pm 41(0.002)$ & $58,886 \pm 6,714(0.001)$
\end{tabular}

$(\mathrm{C} 3 \mathrm{Heb} \times \mathrm{C} 57 \mathrm{BL} / 6) \mathrm{F}_{1}$ male mice were injected intravenously with different numbers of T10 clone (IE7) tumor cells. $14 \mathrm{~d}$ later, pulmonary metastatic nodules were stained with India ink and counted. Separate groups of mice injected with the same number of tumor cells were injected with $25 \mu \mathrm{g} /$ mouse FUdR, i.p. followed by $1 \mu \mathrm{Ci} / \mathrm{mouse}{ }^{125} \mathrm{I}-\mathrm{UdR}$. The weight of lungs and the incorporation of ${ }^{125} \mathrm{I}-\mathrm{UdR}$ into the lungs were determined $24 \mathrm{~h}$ later.

* $\pm \mathrm{SE}$. The numbers in parentheses represent the $P<$ values of each group when analyzed in comparison with group 1 .

tases, halothane and $\mathrm{N}_{2} \mathrm{O}$ being the most potent stimulators of 3LL metastatic growth. In fact, not only were lung metastases enhanced following surgery performed under anesthesia, but the development of liver metastases in animals anesthetized with kethalar, halothane, and $\mathrm{N}_{2} \mathrm{O}$ was significantly enhanced. The increase in ${ }^{125} \mathrm{I}-\mathrm{UdR}$ uptake in the spleen of tumorbearing mice was correlated with the occurrence of splenomegaly in these animals as we have previously described (24). This was attributed to the proliferation of spleen cell populations, possibly in response to growth of the local tumor.

TABLE II

Effect of Anesthetic Drugs on Metastatic Growth in Tumor-excised 3LL-bearing Mice

\begin{tabular}{|c|c|c|c|c|c|c|}
\hline \multirow[b]{2}{*}{ Group } & \multirow[b]{2}{*}{ Treatment } & \multirow{2}{*}{$\begin{array}{l}\text { No. of mice } \\
\text { per group }\end{array}$} & \multirow{2}{*}{$\begin{array}{l}\text { Weight of } \\
\text { lungs }\end{array}$} & \multicolumn{3}{|c|}{${ }^{125}$ I-UdR incorporation } \\
\hline & & & & Lungs & Liver & Spleen \\
\hline & & & $m g^{*}$ & & $c p m^{*}$ & \\
\hline 1 & Non-TBM, $\$$ nonamputated & 5 & $180 \pm 24$ & $623 \pm 61$ & $2,851 \pm 296$ & $3,266 \pm 754$ \\
\hline 2 & TBM w/o anesthesia, nonamputated & 17 & $196 \pm 6$ & $1,676 \pm 107$ & $4,066 \pm 350$ & $12,979 \pm 1,837$ \\
\hline 3 & TBM w/o anesthesia, amputated & 10 & $199 \pm 4$ & $1,367 \pm 149$ & $3,260 \pm 173$ & $10,913 \pm 1,423$ \\
\hline 4 & $\begin{array}{l}\text { TBM with pentothal sodium } \\
\text { anesthesia, amputated }\end{array}$ & 7 & $\begin{array}{r}318 \pm 67 \\
(0.001)\end{array}$ & $\begin{array}{c}2,300 \pm 630 \\
(0.15)\end{array}$ & $\begin{array}{c}3,660 \pm 342 \\
(0.15)\end{array}$ & $\begin{array}{c}10,066 \pm 1,577 \\
(0.35)\end{array}$ \\
\hline 5 & $\begin{array}{l}\text { TBM with kethalar anesthesia, } \\
\text { amputated }\end{array}$ & 9 & $\begin{array}{l}223 \pm 19 \\
\quad(0.4)\end{array}$ & $\begin{array}{l}2,183 \pm 281 \\
(0.006)\end{array}$ & $\begin{array}{l}4,692 \pm 851 \\
(0.013)\end{array}$ & $\begin{array}{c}7,978 \pm 1,232 \\
(0.6)\end{array}$ \\
\hline 6 & $\begin{array}{l}\text { TBM with halothane anesthesia, } \\
\text { amputated }\end{array}$ & 8 & $\begin{array}{r}426 \pm 101 \\
(0.0019)\end{array}$ & $\begin{array}{c}5,668 \pm 1,163 \\
(0.0006)\end{array}$ & $\begin{array}{l}5,775 \pm 1,918 \\
(0.0001)\end{array}$ & $\begin{array}{c}8,870 \pm 1,622 \\
(0.4)\end{array}$ \\
\hline 7 & $\begin{array}{l}\text { TBM with } \mathrm{N}_{2} \mathrm{O} \text { anesthesia, } \\
\text { amputated }\end{array}$ & 8 & $\begin{array}{l}483 \pm 72 \\
(0.0003)\end{array}$ & $\begin{array}{l}4,857 \pm 1,386 \\
(0.003)\end{array}$ & $\begin{array}{l}7,906 \pm 1,435 \\
(0.001)\end{array}$ & $\begin{array}{c}20,100 \pm 6,889 \\
(0.5)\end{array}$ \\
\hline
\end{tabular}

C57BL/6 male mice were injected intrafootpad with $1 \times 10^{5} 3 \mathrm{LL}$ cells. When the tumor reached 6-8 mm Diam, the tumorbearing mice were exposed to anesthetic drugs and the primary tumor was surgically removed. $10 \mathrm{~d}$ later, mice were injected with $25 \mu \mathrm{g} /$ mouse FUdR i.p. and then with $1 \mu \mathrm{Ci}$ /mouse ${ }^{125} \mathrm{I}-\mathrm{UdR}$. The weight of lungs and the ${ }^{125} \mathrm{I}-\mathrm{UdR}$ incorporation into various organs was determined $24 \mathrm{~h}$ later.

* \pm SE. The numbers in parentheses represent the $P<$ value of each group statistically analyzed in comparison with group 3 . † TBM, tumor-bearing male. 
TABLE III

The Effect of Anesthetic Drugs on Metastatic Growth in Tumor-excised B16 Melanoma-bearing Mice

\begin{tabular}{|c|c|c|c|c|c|}
\hline \multirow[b]{2}{*}{ Group } & \multirow[b]{2}{*}{ Treatment } & \multirow{2}{*}{$\begin{array}{l}\text { No. of mice } \\
\text { per group }\end{array}$} & \multicolumn{3}{|c|}{${ }^{125} \mathrm{I}$-UdR incorporation } \\
\hline & & & Lungs & Liver & Spleen \\
\hline & & & \multicolumn{3}{|c|}{$c p m$} \\
\hline 1 & Non-TBM, $\ddagger$ nonamputated & 5 & $822 \pm 211$ & $2,881 \pm 611$ & $1,541 \pm 496$ \\
\hline 2 & TBM without anesthesia, nonamputated & 5 & $2,166 \pm 470$ & $7,873 \pm 4,679$ & $19,300 \pm 4,725$ \\
\hline 3 & TBM without anesthesia, amputated & 10 & $2,401 \pm 536$ & $4,554 \pm 1,118$ & $7,736 \pm 1,241$ \\
\hline 4 & TBM with pentothal sodium anesthesia, amputated & 11 & $\begin{array}{c}2,286 \pm 335 \\
(0.5)\end{array}$ & $\begin{array}{c}6,707 \pm 2,234 \\
(0.009)\end{array}$ & $\begin{array}{c}5,865 \pm 822 \\
(0.5)\end{array}$ \\
\hline 5 & TBM with kethalar anesthesia, amputated & 9 & $\begin{array}{c}7,142 \pm 1,883 \\
(0.0002)\end{array}$ & $\begin{array}{c}4,745 \pm 1,076 \\
(0.014)\end{array}$ & $\begin{array}{c}11,733 \pm 2,283 \\
(0.4)\end{array}$ \\
\hline 6 & TBM with halothane anesthesia, amputated & 11 & $\begin{array}{c}3,651 \pm 1,063 \\
(0.5)\end{array}$ & $\begin{array}{c}4,311 \pm 1,401 \\
(0.5)\end{array}$ & $\begin{array}{c}7,152 \pm 1,080 \\
(0.5)\end{array}$ \\
\hline 7 & TBM with $\mathrm{N}_{2} \mathrm{O}$ anesthesia, amputated & 10 & $\begin{array}{c}3,873 \pm 799 \\
(0.15)\end{array}$ & $\begin{array}{c}11,364 \pm 3,701 \\
(0.0014)\end{array}$ & $\begin{array}{c}10,028 \pm 1,603 \\
(0.037)\end{array}$ \\
\hline
\end{tabular}

C57BL/6 male mice were injected intrafootpad with $1 \times 10^{6} \mathrm{~B} 16$ melanoma cells. When the tumor reached 6-8 mm Diam, the tumor-bearing mice were exposed to anesthetic drugs and the primary tumor was excised. $10 \mathrm{~d}$ later, mice were injected with 25 $\mu \mathrm{g} /$ mouse FUdR i.p. followed by $1 \mu \mathrm{Ci}$ /mouse ${ }^{125} \mathrm{I}-\mathrm{UdR}$. The rate of ${ }^{125} \mathrm{I}-\mathrm{UdR}$ incorporation into the various organs was determined $48 \mathrm{~h}$ later.

* \pm SE. The numbers in parentheses represent $P<$ values of each group analyzed statistically in comparison with group 3 .

$\ddagger$ TBM, tumor-bearing mice.

We tested subsequently the effect of anesthetic drugs on the development of metastasis following surgical removal of the B16 melanoma. The experimental design was similar to that described for the $3 \mathrm{LL}$ carcinoma. The results (Table III) show that the growth of lung metastases was significantly enhanced in animals who had undergone surgery under kethalar anesthesia, although a significant increase took place also when anesthesia was performed with halothane and $\mathrm{N}_{2} \mathrm{O}$. $\mathrm{N}_{2} \mathrm{O}$ was the most potent stimulator of the development of postsurgical liver metastases. The increase in ${ }^{125}$ I-UdR uptake observed in spleens of animals anesthetized with $\mathrm{N}_{2} \mathrm{O}$ may well reflect the stimulation of metastatic proliferation in the spleen.

We then tested whether tumors, which under normal conditions do not produce detectable metastases, do so in animals treated with anesthetic drugs. Two clones of tumor cells produced in our laboratory, IC9 and IE7, derived from T10 sarcoma, were used. Although derived from the same tumor, these clones differed from each other in two properties $(17,18)$ : (a) cells of the IE7 clone expressed both parental major histocompatibility complex coded haplotypes, i.e., the $\mathrm{H}-2^{\mathrm{k}}$ and the $\mathrm{H}-2^{\mathrm{b}}$; cells of the IC9 clone expressed only the $\mathrm{H}-2^{\mathrm{b}}$ haplotype; $(b)$ the IE7 clone produced lung metastases in syngeneic animals, whereas the IC9 (which expressed only the $\mathbf{H}-2^{\mathrm{b}}$-associated alloantigens) was incapable of producing detectable lung metastases when transplanted or injected intravenously into immune intact recipients. It produced metastases only in animals that had been immunologically suppressed by total body irradiation.

Assuming that the anesthetic drugs used led to immunosuppression, it was of interest to test whether these drugs enabled the generation of metastases by

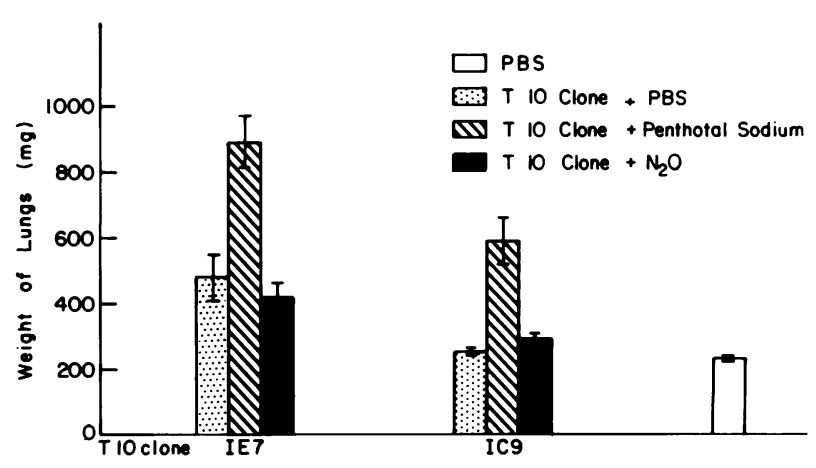

FIGURE 1 Effect of anesthetic drugs on the generation of metastases by T10 sarcoma clones, I. $(\mathrm{C} 3 \mathrm{Heb} \times \mathrm{C} 57 \mathrm{BL} / 6) \mathrm{F}_{1}$ mice were injected with $10^{6} \mathrm{~T} 10$ cloned tumor cells (IE7 and IC9) intravenously, following their exposure to $\mathrm{N}_{2} \mathrm{O}$ or pentothal sodium. The total mass of the experimentally induced pulmonary metastases was determined by weighing the lungs $15 \mathrm{~d}$ after intravenous inoculation. Control syngeneic mice were injected with PBS. There were 10 mice in each experimental group. 
tumor cells of the IC9 clone. We therefore injected IC9 cells intravenously into mice treated with pentothal sodium or $\mathrm{N}_{2} \mathrm{O} .15 \mathrm{~d}$ after the tumor inoculation these mice were tested for the presence of metastases. In parallel, the excised lungs from these mice were photographed after treatment according to Wexler's technique (22). The results (Figs. 1-3) demonstrated that in animals treated with pentothal sodium tumor cells of the IC9 clone did produce lung metastases. Cells of the IE7 clone produced a higher metastatic load in animals treated with pentothal sodium than in unanesthetized recipients. Treatment with $\mathrm{N}_{2} \mathrm{O}$ did not affect production of metastases by $\mathrm{T} 10$ tumor clones.

\section{DISCUSSION}

Previous studies in our laboratory concerning the postsurgical growth of metastases indicated that without anesthesia, surgical excision of the local 3LL tumor was followed by accelerated growth of lung metastases (24). We showed that the local tumor exerts a suppressive effect on its metastases, which is abrogated when the tumor is excised. This suppression measured by the postsurgical acceleration of lung metastasis is a function of the kinetics of growth of the local tumor $(25,26)$, and of the size and mass of the local tumor at the time of excision. In the present study we performed excision without anesthesia of tumors $6-8 \mathrm{~mm}$ in

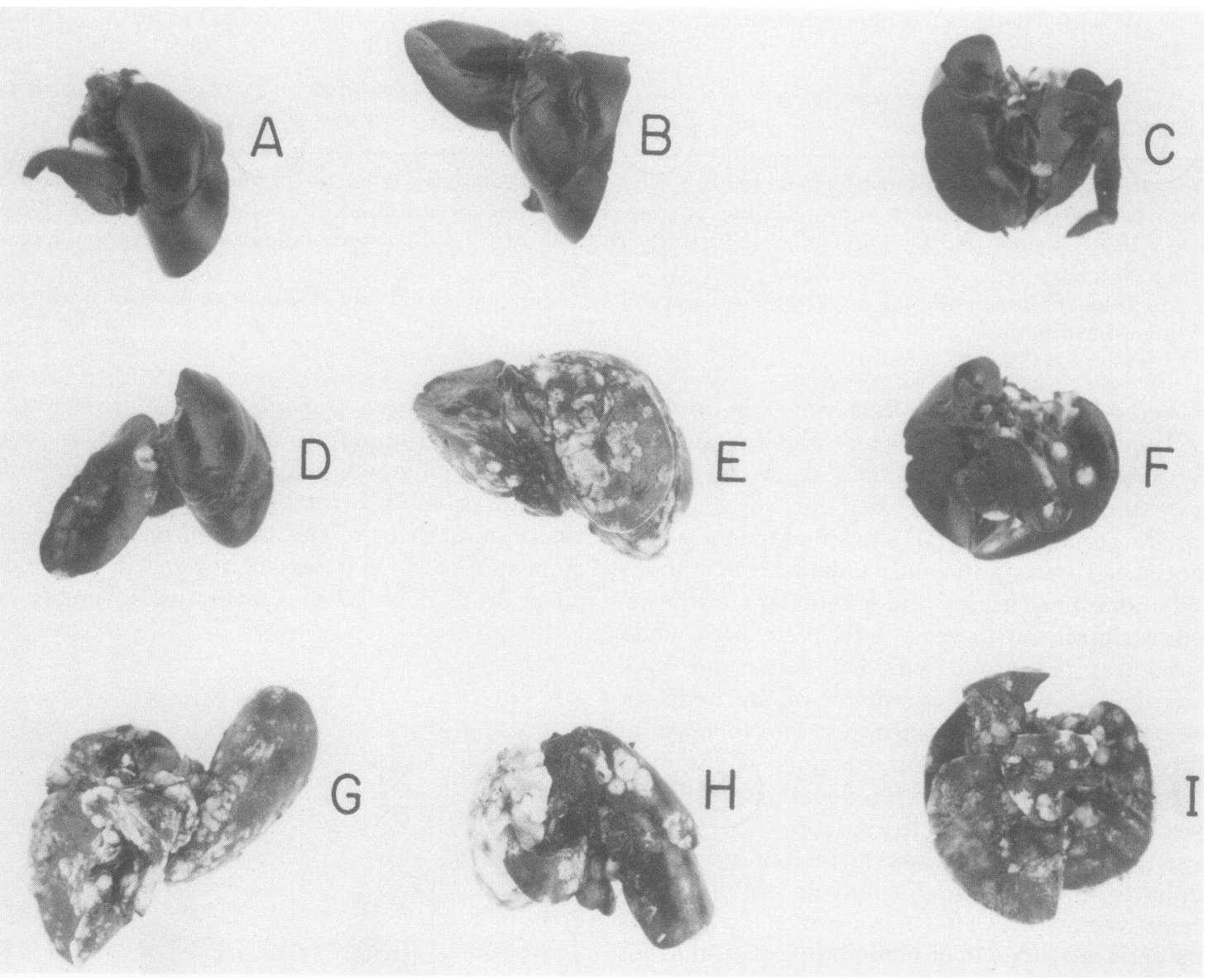

FIGURE 2 Effect of anesthetic drugs on the generation of metastases by T10 sarcoma clones, II. $(\mathrm{C} 3 \mathrm{Heb} \times \mathrm{C} 57 \mathrm{BL} / 6) \mathrm{F}_{1}$ male mice were injected intravenously with $1 \times 10^{6} \mathrm{~T} 10$ cloned tumor cells (IE7 and IC9) after exposure to either $\mathrm{N}_{2} \mathrm{O}$ or pentothal sodium. $14 \mathrm{~d}$ later, mice were killed and India ink was introduced into their lungs by intratracheal injections according to Wexler's technique (22). The metastatic nodules appeared white and the rest of the lung was black. (A) Untreated mouse; (B) mouse treated with pentothal sodium; (C) mouse treated with $\mathrm{N}_{2} \mathrm{O}$; (D) mouse injected intravenously with IC9 tumor cells; (E) mouse treated with pentothal sodium and injected intravenously with IC9 tumor cells; (F) mouse treated with $\mathrm{N}_{2} \mathrm{O}$ and injected intravenously with IC9 tumor cells; (G) mouse injected intravenously with IE7 tumor cells; $(\mathrm{H})$ mouse treated with pentothal sodium and injected intravenously with IE7 tumor cells; (I) mouse treated with $\mathrm{N}_{2} \mathrm{O}$ and injected intravenously with IE7. 


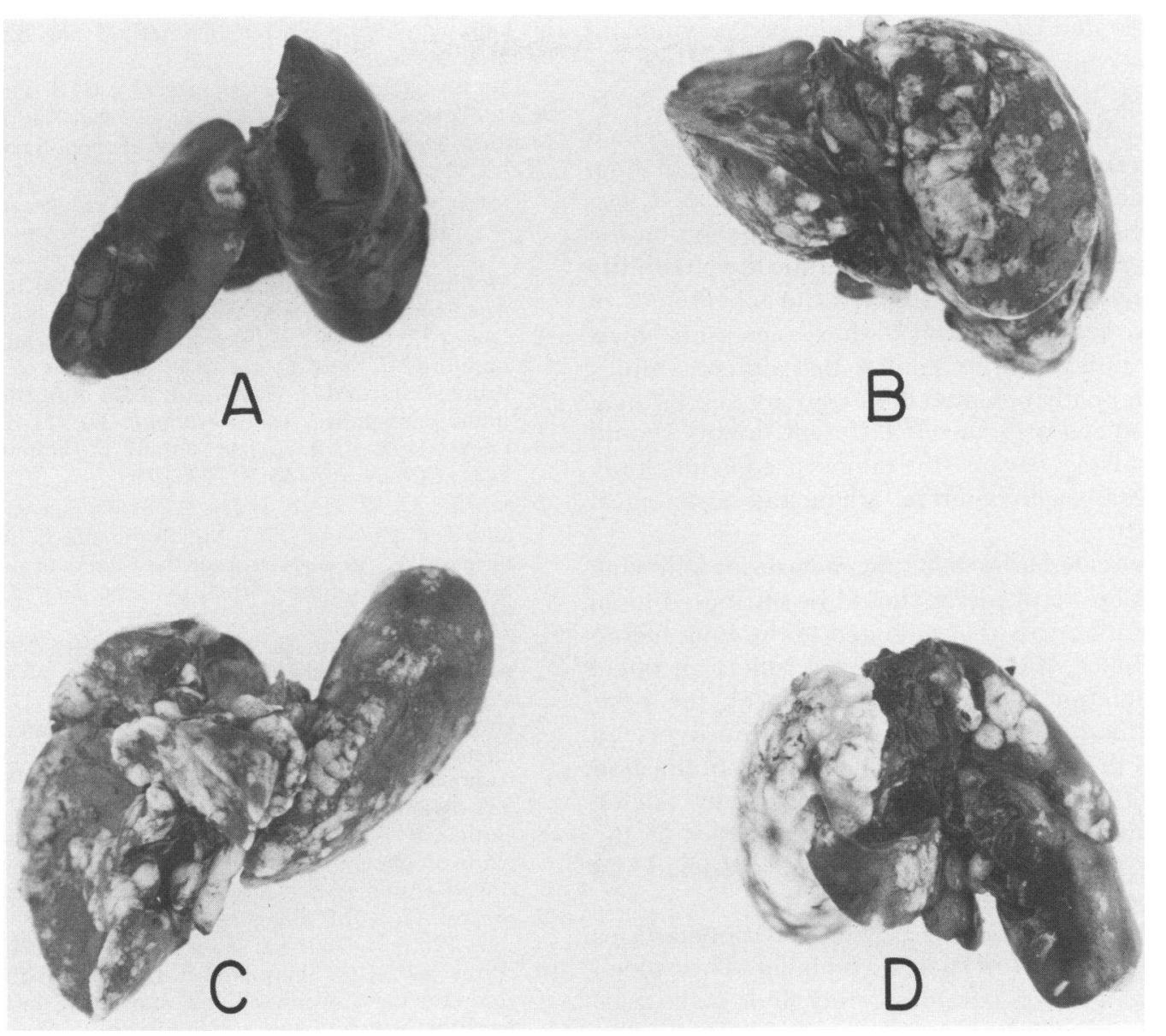

FIgURE 3 Effect of anesthetic drugs on the generation of metastases by T10 clones, III. Mice were treated as described in the legend to Fig. 2. (A) Mouse injected intravenously with IC9 tumor cells; (B) mouse treated with pentothal sodium and injected intravenously with TC9 tumor cells; (C) mouse injected intravenously with IE7 tumor cells; (D) mouse treated with pentothal sodium and injected intravenously with IE7 tumor cells.

diameter, a size at which one does not observe accelerated lung metastasis compared with tumor-bearing mice not having undergone tumor excision. However, when surgical excision of the local tumor was performed under anesthesia, the development of metastasis by both the 3LL carcinoma and the B 16 melanoma was significantly accelerated with each of the four drugs tested. Halothane and $\mathrm{N}_{2} \mathrm{O}$ were found to cause a greater acceleration of both lung and liver 3LL metastasis than sodium pentothal and kethalar. When applied during surgical excision of the B16 melanoma, kethalar had the greatest effect in promoting lung metastases, although $\mathrm{N}_{2} \mathrm{O}$ was the most potent stimulator of liver metastasis.

We also studied cells of two clones of the T10 sarcoma, the IE7 and IC9 clones. The T10 tumor was induced in a $(\mathrm{C} 3 \mathrm{H} \times \mathrm{C} 57 \mathrm{BL} / 6) \mathrm{F}_{1}$ mouse by 3methylcholanthrene. Following in vitro cloning of this tumor, we found that the majority of the clones ex- pressed only the parental $\mathrm{H}-2^{\mathrm{b}}$ haplotype and a minority expressed both, the $\mathrm{H}-2^{\mathrm{b}}$ and the $\mathrm{H}-2^{\mathrm{k}}$ haplotypes. Clones expressing only the $\mathrm{H}-2^{\mathrm{b}}$ haplotype, such as the IC9 clone tested in our present study failed to produce metastasis even when injected intravenously into immune intact mice. Clones expressing exclusively the $\mathrm{H}-2^{\mathrm{b}}$ haplotype were capable of producing metastasis only when injected into recipients which had undergone immune suppression by total body irradiation $(17,18)$. Clones expressing both the $\mathrm{H}-2^{\mathrm{k}}$ and the $\mathrm{H}-2^{\mathrm{b}}$ haplotypes, such as the IE7, were highly metastatic. We found that in animals treated with pentothal sodium the IC9 clone did produce metastasis and the IE7 produced a higher metastatic burden than in nontreated mice.

Although we found that anesthetic drugs strongly accelerated metastasis, we cannot at this stage attribute the activity of these drugs to an effect on a defined target cell, let alone on a defined cellular component. 
The documented effects of anesthetics on the lymphoid system (3-13), and the effect we observed on the capacity of the IC9 clone to produce detectable metastasis only when injected into recipients which were immune-suppressed by total body irradiation, suggest that the anesthetic drugs may accelerate metastasis development by their suppressive action on the immune system. Yet one cannot exclude the possibility that the anesthetic drugs affected the membranes of the tumor cells themselves, thus increasing their metastatic potency. The finding that different drugs were differentially potent in their capacity to accelerate growth of metastases of our different tumors should not be surprising, because the tumors used in this study differed from each other in origin and histological characteristics.

The accelerated growth of lung metastases following excision of the local tumor should be attributed to an effect on tumor cells that migrated to the lung before surgery. Hence, the result does not reflect an effect on the migration of metastatic cells. Yet, the postsurgical effect on metastatic growth in the liver and possibly in the spleen may be due to the mobilization of tumor cells from the lungs to other organs. Such a process may result from effects of anesthetics on the fluidity of the tumor cell membrane, and shedding of membrane components (27).

The effect of $\mathrm{N}_{2} \mathrm{O}$ on the growth of $\mathrm{B} 16$ metastases in the spleen deserves special comment. The spleen is an organ in which one only rarely finds metastases produced by sarcomas or carcinomas. Even intravenous inoculation of normal recipients with the $3 \mathrm{LL}$ or $\mathrm{B} 16$ cells does not result in progressive metastasis in the spleen. Analysis of the mechanisms by which $\mathrm{N}_{2} \mathrm{O}$ accelerates the growth of metastases may suggest an approach to the processes involved in preventing metastatic growth in the spleen.

In summary, whatever the mechanism by which anesthetic drugs promote metastatic growth, the present experiments indicate clearly that anesthetic drugs used during surgical excision of two different mouse tumors may cause a significant increase in metastatic spread and progression. These drugs also caused the spread of metastases to organs in which metastases are otherwise not found. In addition, cells of a nonmetastatic clone of the T10 sarcoma produced metastases when injected intravenously to anesthesized recipients. Finally, our observations apply only to three mouse tumors. The question whether similar phenomena of metastatic acceleration occur with other tumor systems in mice or in other mammals, or with other anesthetics requires further study.

\section{ACKNOWLEDGMENTS}

We would like to thank Ms. A. Karasikov for her excellent assistance in the statistical analysis and Mr. A. Shetzen for his help in applying Wexler's method. Ms. M. Baer provided editorial assistance.

This investigation was supported by U. S. Public Health Service grant CA28139 awarded by the National Cancer Institute, Department of Health and Human Services.

\section{REFERENCES}

1. Walton, B. 1978. Anesthesia, surgery and immunology. Anaesthesia (Lond.) 33: 322-348.

2. Lee, Y. T. N. 1977. Effect of anesthesia and surgery on immunity. J. Surg. Oncol. 9(5): 425-430.

3. Bruce, D. L., and D. W. Wirgard. 1971. Anesthesia and the immune response. Anesthesiology. 34: 271-282.

4. Lecky, J. H. 1975. Anesthesia and the immune system. Surg. Clin. N. Am. 55:(4): 795-799.

5. Fairlie, C. W., T. P. Barss, A. B. French, C. M. Jones, and H. K. Beecher. 1951. Metabolic effects of anesthesia in man. IV. A comparison of the effects of certain anesthetic agents on the normal liver. N. Engl. J. Med. 244: 615-622.

6. Cooperman, L. H., H. Wollman, and M. L. Marsh. 1977. Anesthesia and the liver. Surg. Clin. N. Am. 57(2): 421-428.

7. Humphrey, L. J., D. W. Wingard, and R. Lang. 1969. The effect of surgery and anesthesia on the immunologic responsiveness of the rat. Surgery (St. Louis). 65: 939-942; 946-951.

8. Cullen, B. F. 1974. The effects of halothane and nitrous oxide on phogocytosis and human leucocyte metabolism. Anesth. Analg. Curr. Res. (Cleveland). 53: 531-536.

9. Stossel, T. 1974. Phagocytosis. N. Engl. J. Med. 290: 717-726, 774-780, 833-839.

10. Nunn, J. F., J. A. Sharp, and R. L. Kimball. 1970. Reversible effects on an inhalational anesthetic on lymphocyte motility. Nature (Lond.). 226: 85-86.

11. Bruce, D. L. 1972. Halothane inhibition of phytohemagglutinin-induced transformation of lymphocytes. Anesthesiology. 36: 201-205.

12. Bruce, D. L., H. S. Liu, W. R. Bruce. 1970. Reduction of colony forming cell sensitivity to arabinosyl cytosine by halothane anesthesia. Cancer Res. 30: 1803-1805.

13. Quin, J. W., and A. D. Shannon. 1975. The effect of anesthesia and surgery on lymph flow, protein and leucocyte concentration in lymph of the sheep. Lymphology (Stuttgart). 8(4): 126-135.

14. Pollard, M., C. R. Burleson, and P. H. Luckett. 1977. Factors that modify the rate and extent of spontaneous metastases of prostate tumors in rats. In: Cancer Invasion and Metastasis: Biologic Mechanisms and Therapy. S. B. Day, W. P. L. Myers, P. Stansly, S. Garattini, and M. G. Lewis, editors. Raven Press, New York. 357366 .

15. Sugiura, K., and C. C. Stock. 1955. Studies in a tumor spectrum. III. The effects of phosphoramides on the growth of a variety of mouse and rat tumors. Cancer Res. 15: 38-51.

16. Biological materials. In: Handbook on Genetically Standardized Jax Mice. 1968. E. H. Green, editor. Bar Harbor, Maine. 51-66.

17. Katzav, S., P. De Baetselier, E. Gorelik, M. Feldman, and S. Segal. 1981. Immunogenetic control of metastasis formation by methyl-cholanthrane-induced Tumor (T10) in mice. Differential expression of $\mathrm{H}-2$ gene products. Transplant Proc. 13: 742-746.

18. De Baetselier, P., S. Katzav, E. Gorelik, M. Feldman, and S. Segal. 1980. Differential expression of $\mathrm{H}-2$ gene 
products in tumor cells is associated with their metastatogenic properties. Nature (Lond.). 288: 179-181.

19. Brodt, P., and J. Gordon, 1978. Anti-tumor immunity in B lymphocyte deprived mice. I. Immunity to chemicallyinduced tumor. J. Immunol. 121: 352-359.

20. Bonmassar, E., D. Houchens, M. Fioretti, and A. Goldin. 1975. Uptake of 5-iododeoxythymidine as a measure of tumor growth and tumor inhibition. Chemotherapy. 21: 321-329.

21. Bennett, M., G. Cudkowicz, R. S. Foster, and D. Metcalf. 1968. Hemopoietic progenitor cells of $W$ anemic mice studied in vivo and in vitro. J. Cell. Physiol. 71: 211-226.

22. Wexler, H. 1966. Accurate identification of experimental pulmonary metastases. J. Natl. Cancer Inst. 36: 641-645.

23. Siegel, S. 1956. Nonparametric Statistics for the Behavioral Sciences. McGraw-Hill Book Co., Inc., New York. 116-126.
24. Gorelik, E., S. Segal, and M. Feldman. 1979. Growth of a local tumor exerts a specific inhibitory effect on progression of lung metastases. Int. J. Cancer (Kobenhavn). 21: $617-625$.

25. Gorelik, E., S. Segal, and M. Feldman. 1980. Host's immune state and kinetics of local tumor growth control the progression of postoperative lung metastasis. In: Recent Results in Cancer Research. G. Mathé and F. M. Muggia, editors. Springer-Verlag, New York, Inc. 75: 20-28.

26. Gorelik, E., S. Segal, and M. Feldman. 1980. Control of lung metastasis progression in mice: role of growth kinetics of 3LL Lewis lung carcinoma and host immune reactivity. J. Natl. Cancer Inst. 65: 1257-1264.

27. Poste, G. and I. J. Fidler. 1980. The pathogenesis of cancer metastasis. Nature (Lond.). 283: 146-159. 